\title{
Localization of oestrogen receptor $\alpha$, oestrogen receptor $\beta$ and androgen receptors in the rat reproductive organs
}

\author{
G Pelletier, C Labrie and F Labrie \\ Molecular Endrocrinology Laboratory, CHUL Research Center of Laval University, 2705 Laurier Boulevard, St Foy, Quebec G1V 4G2, Canada \\ (Requests for offprints should be addressed to G Pelletier; Email: LREM@crchul.ulaval.ca)
}

\begin{abstract}
There is now evidence that oestrogens and androgens can influence male and female reproductive systems. In order to accurately identify the sites of action of oestrogens and androgens, we have proceeded to the histological localization of the two oestrogen receptor (ER) subtypes, ER $\alpha$ and $\operatorname{ER} \beta$, and the androgen receptor (AR) in the reproductive tissues of adult rats of both sexes. AR was detected by immunocytochemistry, while $\operatorname{ER} \alpha$ and $\operatorname{ER} \beta$ were localized by both immunocytochemistry and in situ hybridization. In the pituitary gland of animals of both sexes, ER $\alpha$ was found in the majority of nuclei of secretory cells in the anterior pituitary. The intermediate and posterior lobes did not show any staining. ER $\beta$ was not found to be expressed in any of the pituitary lobes. Using AR antibodies, nuclear staining was detected in about $50 \%$ of secretory cells of the anterior lobe, the intermediate and posterior lobes being completely unstained. In the testis, ER $\alpha$ was localized in nuclei of Leydig cells as well as in round spermatocytes and spermatids, while ER $\beta$ could only be detected in Sertoli cell nuclei. AR immunoreactivity was found in nuclei of Sertoli, peritubular myoid and Leydig cells. In the prostate, ER $\beta$ was observed in epithelial cells of tubulo-alveoli, while the stroma was unlabelled. ER $\alpha$ was not found to be expressed in any
\end{abstract}

prostate cells. In the prostate, AR was detected in nuclei of epithelial, stromal and endothelial cells. In seminal vesicles, staining of ER $\alpha$ was found in nuclei of epithelial and stromal cells. Similar findings were observed using AR antibodies. While ER $\beta$ mRNA could not be detected by in situ hybridization, weak staining for $\operatorname{ER} \beta$ was localized in epithelial cells of seminal vesicles. In the ovary, both $\operatorname{ER} \alpha$ and $\operatorname{ER} \beta$ were found to be expressed. $\operatorname{ER} \beta$ mRNA was found in granulosa cells of growing follicles, while ER $\alpha$ was present in theca cells, interstitial gland cells and germinal epithelium. AR immunoreactivity was detected in granulosa cell nuclei in growing follicles and also in scattered interstitial cells. In the oviduct and uterus, ER $\alpha$ was observed in nuclei of epithelial cells as well as of stromal and muscle cells. Similarly, AR immunoreactivity was present in nuclei of epithelial cells, stromal and muscle cells in both the oviduct and uterus. ER $\beta$ was not detected in the oviduct and uterus. The present findings indicate a cell-specific localization of ER $\alpha, E R \beta$ and AR in reproductive tissues in rats of both sexes. By establishing the precise sites of action of oestrogens and androgens they contribute to a better understanding of the respective role of these steroids in reproduction function.

Journal of Endocrinology (2000) 165, 359-370

\section{Introduction}

Oestrogens play an important role in the growth, differentiation and function of female and male reproductive tissues (for review see Clark et al. 1992, Sharpe 1998). The effects of oestrogens are mediated through an intracellular oestrogen receptor (ER), a member of the steroid/thyroid hormone receptor superfamily which regulates gene transcription via the oestrogen-responsive element (Mangelsdorf et al. 1995). Recently, a second ER called ER $\beta$ has been cloned from a rat prostate library (Kuiper et al. 1996) and the original one is now designated as ER $\alpha$. RT-PCR analysis and in situ hybridization have established that the highest levels of ER $\beta$ mRNA are in the rat ovary and prostate (Kuiper et al. 1996, 1997). So far, there have been very few reports on the cellular localization of
$\mathrm{ER} \beta$ in the female and male rat reproductive organs (Kuiper et al. 1996, 1997, Byers et al. 1997, Saunders et al. 1998, Sar \& Welsch 1999).

Androgens are involved in the development and physiological function of male accessory sex organs as well as in the functioning of several other organs and tissues (Carson-Jurica et al. 1990). The androgen action is mediated by the androgen receptor (AR) which also belongs to the superfamily of ligand-responsive transcription regulators (Evans 1988, Carson-Jurica et al. 1990). By immunocytochemistry, AR have been localized in a variety of human tissues, including reproductive tissues in both sexes (Ruizeveld de Winter et al. 1991, Kimura et al. 1993). Similarly, in the rat, AR have also been localized not only in male but also in female reproductive tissues (Sar et al. 1990, Hirai et al. 1994, Tetsuka et al. 1995). 
For a better understanding of the role of androgens and oestrogens in the different reproductive tissues it appears important to define the exact site(s) of action of these sex steroids. Then, in order to accurately determine cells expressing AR, ER $\alpha$ and $\mathrm{ER} \beta$ in rat reproductive tissues, we have proceeded to the simultaneous localization of these receptors using immunocytochemistry as well as in situ hybridization.

\section{Materials and Methods}

\section{Animals}

Six adult male (225-250 g) and female (175-200 g) Sprague-Dawley rats were housed under constant temperature $\left(21 \pm 1{ }^{\circ} \mathrm{C}\right)$ and light (lights on from 0600 to 2000 h) regimens. They received Purina chow (RalstonPurina, St Louis, MO, USA) and tap water ad libitum. They were all perfused between 0900 and $1000 \mathrm{~h}$ for histological procedures as described below. The females were on diestrous day 1.

\section{Histological procedures}

All the animals were perfused transcardially with $200 \mathrm{ml}$ $4 \%(\mathrm{w} / \mathrm{v})$ paraformaldehyde in $0 \cdot 1 \mathrm{M}$ phosphate buffer $(\mathrm{pH} 7 \cdot 4)$. The different tissues, namely pituitary, testis, prostate, seminal vesicle, ovary and uterus were excised and post-fixed in the same fixative for $48 \mathrm{~h}$ at $4{ }^{\circ} \mathrm{C}$. For immunocytochemistry, the tissues were embedded in paraffin while, for in situ hybridization, the tissues were placed in $15 \%$ sucrose in $0.1 \mathrm{M}$ phosphate buffer before being quickly frozen in isopentane chilled in liquid nitrogen.

\section{Immunocytochemistry}

Paraffin sections $(5 \mu \mathrm{m})$ were deparaffinized, hydrated and then treated with $3 \% \mathrm{H}_{2} \mathrm{O}_{2}$ in phosphate-buffered saline ( $\mathrm{pH} 7 \cdot 6$ ) for $30 \mathrm{~min}$. These steps were followed by heating the sections in a microwave oven for antigen retrieval using citrate buffer ( $\mathrm{pH} 5 \cdot 5$ ) as previously described (Tacha \& Chen 1994). The sections were then incubated overnight at $4{ }^{\circ} \mathrm{C}$ with AR antibody (see below for details) at a concentration of $1 \mu \mathrm{g} / \mathrm{ml}$ or ER $\alpha$ antibody $(2 \mu \mathrm{g} / \mathrm{ml})$ (see below for details). Control sections were incubated with preadsorbed antibodies as described below. Sections were then washed in Tris-saline ( $\mathrm{pH} 7 \cdot 6)$ and incubated at room temperature for $4 \mathrm{~h}$ with peroxidase-labelled goat anti-rabbit $\gamma$-globulin (Hyclone, Logan, UT, USA) diluted at 1:500 as previously described (Pelletier et al. 1992).

AR An affinity-purified rabbit polyclonal antibody (N-20) against a peptide corresponding to amino acids
299-315 of the AR of human origin (identical to the corresponding mouse sequence) was purchased from Santa Cruz Biotechnology, Inc., Santa Cruz, CA, USA). It reacts with the $A R$ of mouse, rat and human origin as tested by Western blotting and immunohistochemistry. Preadsorbed antibody was prepared by incubating $1 \mu \mathrm{g} / \mathrm{ml}$ AR antibody with $20 \mu \mathrm{g}$ synthetic peptide for $2 \mathrm{~h}$ at room temperature.

ER $\boldsymbol{\alpha}$ To localize ER $\alpha$, we used an affinity-purified rabbit polyclonal antibody (MC-20; Santa Cruz Biotechnology, Inc.) raised against a synthetic peptide corresponding to amino acids 580-599 mapping at the carboxyl-terminus of the ER $\alpha$ of mouse origin. This antibody was used at a concentration of $2 \mu \mathrm{g} / \mathrm{ml}$. For control experiments, the antibody $(2 \mu \mathrm{g} / \mathrm{ml})$ was adsorbed by preincubation with $20 \mu \mathrm{g}$ peptide for $2 \mathrm{~h}$ at room temperature.

ER $\beta$ For ER $\beta$ localization, we used a rabbit polyclonal antibody (06-629: Upstate Biotechnology, Lake Placid, NY, USA) directed against a synthetic peptide corresponding to amino acids $54-71$ of the rat $\operatorname{ER} \beta$. The antibody was used at a concentration of $10 \mu \mathrm{g} / \mathrm{ml}$. For specific control, the antibody was adsorbed by preincubation with $20 \mu \mathrm{g}$ synthetic peptide for $2 \mathrm{~h}$ at room temperature

In the anterior pituitary gland, the percentage of ER $\alpha$ - and AR-expressing cells was obtained by counting a total number of 1000 cells for each sex. The cells exhibiting clear nuclear staining were considered as positive.

\section{In situ hybridization}

Frozen sections $\left(10 \mu \mathrm{m}\right.$ thick) were serially cut at $-20{ }^{\circ} \mathrm{C}$ and mounted onto gelatin- and poly-L-lysine-coated slides. In situ hybridization with cRNA probes was performed as previously described (Givalois et al. 1997). Briefly, the sections were prehybridized at room temperature in a humid chamber for $2 \mathrm{~h}$ in $450 \mu \mathrm{l} /$ slide of a prehybridization buffer containing 50\% formamide, $5 \times \operatorname{SSPE}(1 \times \operatorname{SSPE}$ being $0.1 \mathrm{M} \mathrm{NaCl}, \quad 10 \mathrm{mM}$ $\mathrm{NaH}_{2} \mathrm{PO}_{4} \mathrm{pH} 7 \cdot 4,1 \mathrm{mM}$ EDTA), $5 \times$ Denhart's buffer, $200 \mathrm{mg} / \mathrm{ml}$ denatured salmon testis DNA (Sigma), $200 \mu \mathrm{g} / \mathrm{ml}$ yeast tRNA, $2 \mu \mathrm{g} / \mathrm{ml}$ Poly A (BoehringerMannheim, Montreal, Canada) and 4\% dextran sulphate. After prehybridization treatment, $100 \mu \mathrm{l}$ hybridization mixture (prehybridization buffer containing, in addition, $10 \mathrm{mM}$ dithiothreitol and ${ }^{35} \mathrm{~S}$-labelled cRNA probe at a concentration of $20 \times 10^{6}$ c.p.m. $/ \mathrm{ml}$ was spotted on each slide, sealed under a coverslip and incubated at $37^{\circ} \mathrm{C}$ overnight (15-20 h) in a humid chamber.

After hybridization, coverslips were removed and slides were rinsed in $2 \times \mathrm{SSC}$ at room temperature for $30 \mathrm{~min}$. Sections were digested by RNase A $(20 \mathrm{mg} / \mathrm{ml}$ in $2 \times \mathrm{SSC})$ at $37^{\circ} \mathrm{C}$ for $30 \mathrm{~min}$, rinsed in decreasing 

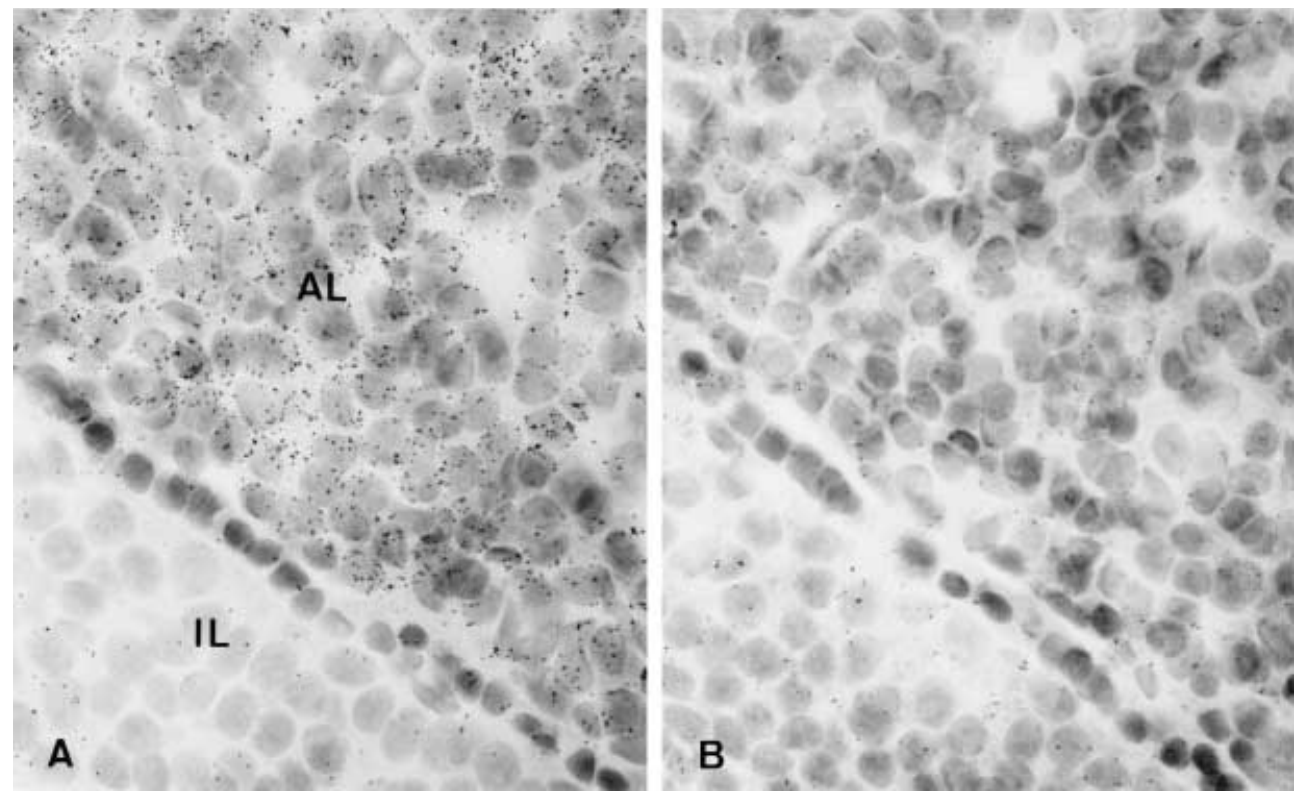

Figure 1 Section through the anterior (AL) and intermediate (IL) pituitary lobe of a male rat. (A) Hybridization with $\mathrm{a}^{35} \mathrm{~S}$-labelled $\mathrm{ER} \alpha$ antisense probe. In the $\mathrm{AL}$, most of the cells appear to be labelled, while IL cells are unlabelled. (B) Hybridization with a labelled ER $\beta$ antisense probe. Only a few dispersed silver grains can be observed. $\times 620$.

concentrations of SSC $(2 \times$ SSC and $1 \times$ SSC $)$ for $30 \mathrm{~min}$ at room temperature, washed in $0.5 \times \mathrm{SSC}$ for $30 \mathrm{~min}$ at $37^{\circ} \mathrm{C}$, followed by $90 \mathrm{~min}$ at room temperature in $0.5 \times \mathrm{SSC}$, at $60{ }^{\circ} \mathrm{C}$ in $0.1 \times \mathrm{SSC}$ and finally for $30 \mathrm{~min}$ at room temperature in $0 \cdot 1 \times \mathrm{SSC}$.

The sections were then dehydrated and exposed onto Kodak X-Omat films for $4-5$ days before being coated with liquid photographic emulsion (Kodak-NTB2; diluted 1:1 with water). Slides were exposed for 14-18 days, developed in Dektol developer (Kodak) for $2 \mathrm{~min}$ and fixed in rapid fixer (Kodak) for $4 \mathrm{~min}$. Thereafter, tissues were rinsed in running water for $30 \mathrm{~min}$, counterstained with haematoxylin and rapidly dehydrated through graded concentrations of ethanol, cleared in toluene and coverslipped with Permount (Fisher Scientific, Montreal, Canada).

\section{cRNA probe preparation}

Specific ER $\alpha$ and ER $\beta$ cRNA probes were prepared as previously described (Laflamme et al. 1998). Briefly, these probes were generated from their respective linearized rat ER cDNA subcloned into a pBluescript II KS(+) plasmid vector. ER $\alpha$ cDNA templates were linearized with BamHI and HindIII for antisense and sense, whereas XbaI and XhoI were used to linearize antisense and sense ER $\beta$ cDNAs respectively. Radioactive cRNA copies were synthesized by incubation of $250 \mathrm{ng}$ linearized plasmid in $6 \mathrm{mM} \mathrm{MgCl}_{2}, 40 \mathrm{mM}$ Tris (pH 7.9), $2 \mathrm{mM}$ spermidine, $10 \mathrm{mM} \mathrm{NaCl}, 10 \mathrm{mM}$ dithiothreitol, $0.2 \mathrm{mM}$ ATP/
GTP/CTP, $200 \mu \mathrm{Ci}\left[\alpha_{-}{ }^{35}\right.$ S]UTP (Dupont NEN, Boston, MA, USA), 40 U RNAsin (Promega, Madison, WI, USA) and $20 \mathrm{U}$ of either T3 (antisense probes) or T7 (sense probes) RNA polymerase for $60 \mathrm{~min}$ at $37^{\circ} \mathrm{C}$.

\section{Results}

In the pituitary gland of both sexes, hybridization signal could be detected only with the ER $\alpha$ cRNA probe (Fig. 1). The autoradiographic reaction was present over the anterior pituitary, the intermediate and posterior lobes being unlabelled. Although a high degree of resolution could not be achieved with the ${ }^{35} \mathrm{~S}-$ labelled probe, it could be considered that the majority of the cells in the anterior pituitary were specifically labelled. Hybridization with the labelled ER $\alpha$ sense probe did not generate specific labelling, silver grains being randomly distributed throughout the three lobes (not shown). No sex difference could be observed. Immunostaining performed with an antibody to ER $\alpha$ revealed a nuclear staining in a large number of cells (approximately 90\%) in the anterior pituitary (Fig. 2). Weak cytoplasmic staining could be consistently visualized in a few cells. The intermediate and posterior lobes showed no staining. Immunoabsorption of the antibody with the antigen completely abolished the nuclear and cytoplasmic staining (not shown). No immnostaining could be obtained with the antibody to ER $\beta$.

In the anterior lobe, immunolocalization with anti-AR produced nuclear labelling in about $50 \%$ of cells (Fig. 3). 


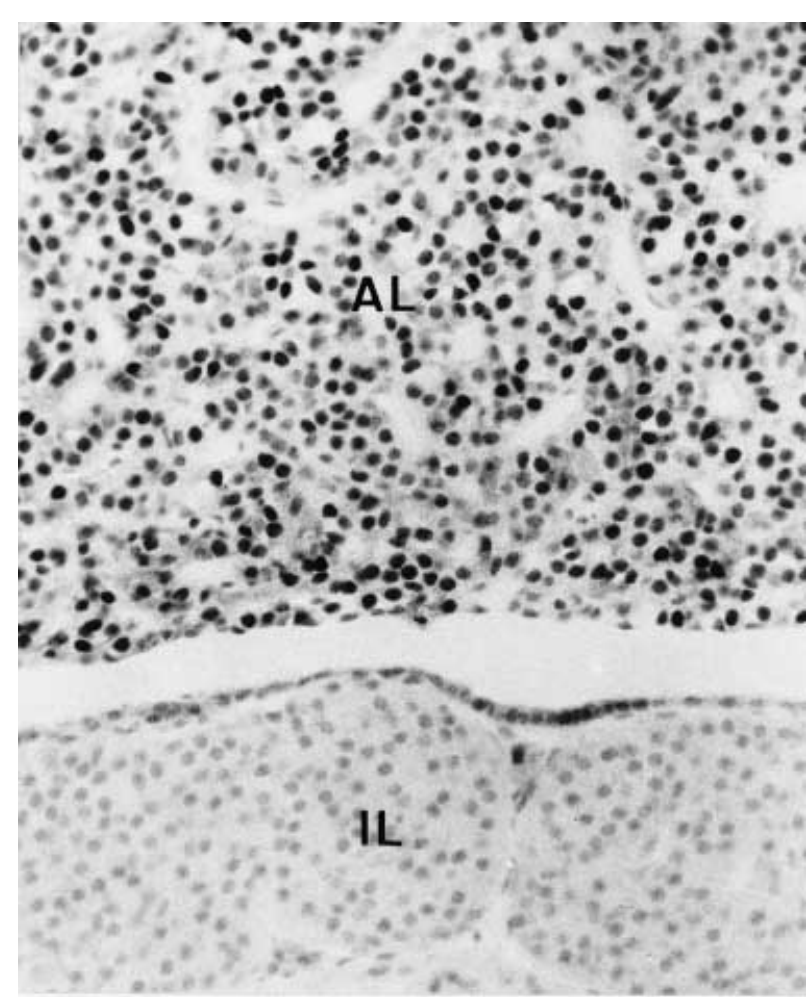

Figure 2 Immunolocalization of ER $\alpha$ in a male rat pituitary. In the anterior lobe $(\mathrm{AL})$, most of the nuclei are stained, while no labelling can be detected in the intermediate lobe (IL). $\times 300$.

Light cytoplasmic staining was also consistently observed in some cells. The nuclei of the epithelial cells lining the pituitary cleft were also stained. No staining was detected in the intermediate and posterior lobes. No difference in staining could observed between male and female pituitaries. Preadsorbed AR antibody did not induce any nuclear or cytoplasmic staining.

\section{Male reproductive organs}

In the testis, in situ hybridization demonstrated, on X-ray films, a strong signal with the ER $\alpha$ probe (Fig. 4A), and a weak labelling with the ER $\beta$ probe (Fig. 4B). At the light microscopic level, the silver grains demonstrating ER $\alpha$ mRNA were associated with the seminiferous epithelium and interstitial cells. In the seminiferous tubules, the grains could be seen over developing spermatids whereas Sertoli cells and germ cells at early stages of differentiation were negative (not shown). Similar results were obtained by immunocytochemistry. ER $\alpha$ immunoreactivity was found in nuclei of Leydig cells as well as in round spermatids and spermatocytes (Fig. 5A). In these germinal cells, the staining was mostly detected in the cytoplasm. Immunostaining for ER $\beta$ was detected in nuclei of cells located at the periphery of the tubules, which are likely Sertoli cells

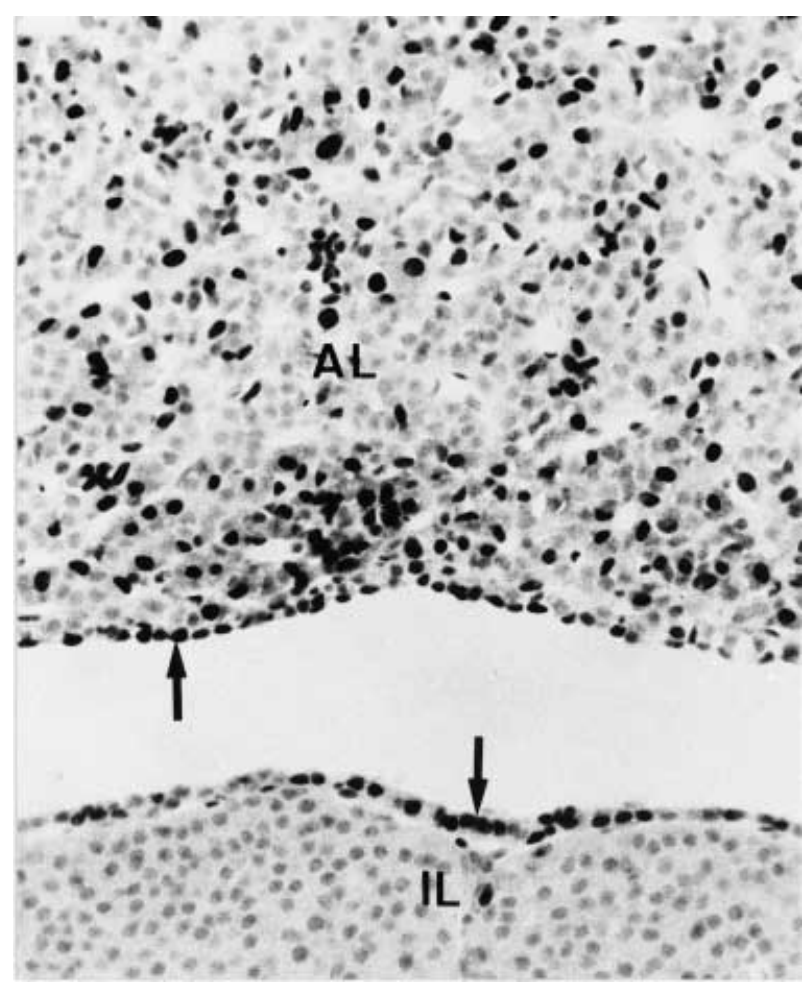

Figure 3 Immunolocalization of AR in a male rat pituitary. In the anterior lobe $(\mathrm{AL})$, several nuclei are immunostained. The nuclei of the epithelial cells lining the pituitary cleft are also labelled (arrows). No labelling can be found in the intermediate lobe (IL). $\times 300$.

(Fig. 6). Similarly, AR immunoreactivity was localized in nuclei of cells, which are presumably Sertoli cells (Fig. 7). Nuclear staining was also present in nuclei of peritubular myoid cells as well as of Leydig cells.

In the prostate, following in situ hybridization for ER $\beta$ mRNA detection, hybridization signal was associated with the epithelial cells of tubulo-alveoli while the stroma cells appeared to be unlabelled (Fig. 8A). Identical results were obtained with immunocytochemistry. It was not possible to detect ER $\alpha$ expression either by in situ hybridization (Fig. 8B) or immunocytochemistry (not shown). ARs were detected in the nuclei of almost all the secretory cells in tubulo-alveoli (Fig. 9). The nuclei of several stromal cells were immunopositive. Endothelial cells in capillaries and larger blood vessels also exhibited nuclear staining.

In seminal vesicles, ER $\alpha$ was detected in the epithelial cells by both in situ hybridization and immunocytochemistry (data not shown). Immunostaining was observed in the nucleus and also to a lesser degree in the cytoplasm of epithelial cells. A few stromal cells exhibiting a light nuclear and cytoplasmic staining were consistently observed. No ER $\beta$ could be detected by in situ hybridization while, by immunocytochemistry, weak nuclear 
A

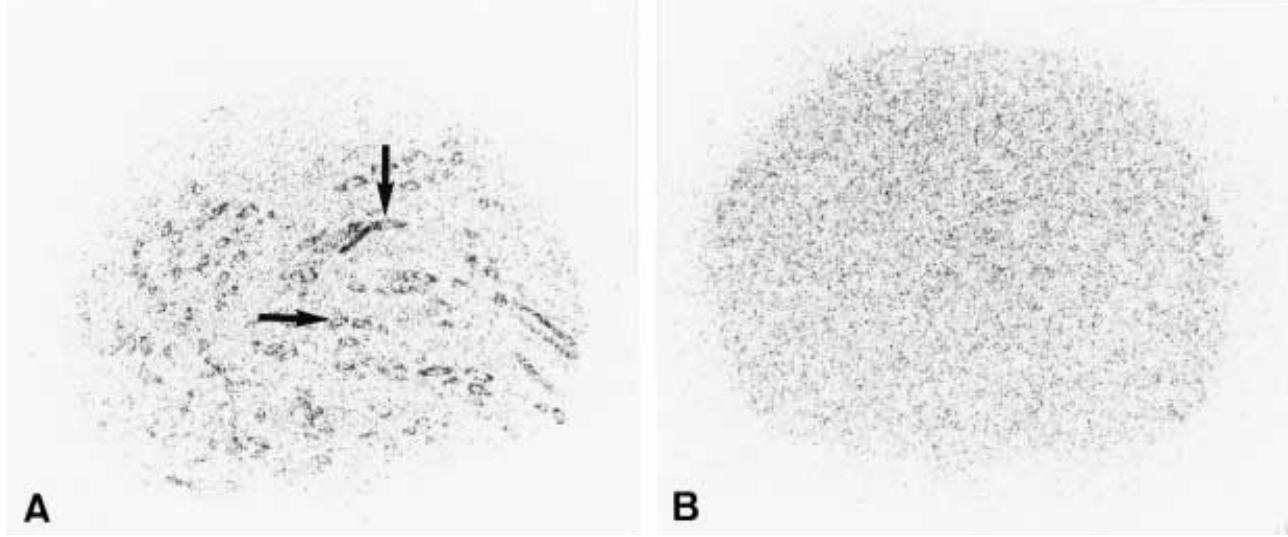

Figure 4 X-ray autoradiographs of a rat testis. (A) Hybridization with a labelled ER $\alpha$ antisense probe. Tubular labelling (arrows) can be observed. (B) Hybridization with a labelled ER $\beta$ antisense probe. No specific labelling can be detected.

labelling was detected in nuclei of epithelial cells. Immunostaining for AR revealed nuclear staining in the epithelial and stromal cells.

\section{Female reproductive tract}

In the ovary, immunocytochemical studies conducted with the antibodies to $\mathrm{ER} \alpha$ revealed that nuclear staining occurred in thecal cells, interstitial gland cells and germinal epithelium (Fig. 10). Granulosa cells in primary, secondary and mature follicles did not exhibit any nuclear staining. Similarly, corpora lutea cells also remained unlabelled. Identical localization of ER $\alpha$ mRNA was obtained by in situ hybridization. ER $\beta$ mRNA expression was evaluated by in situ hybridization. Specific labelling was found in the granulosa cells of growing follicles at all stages from primary to mature follicles, including preovulatory follicles (Fig. 11). Corpora lutea, thecal and interstitial gland cells
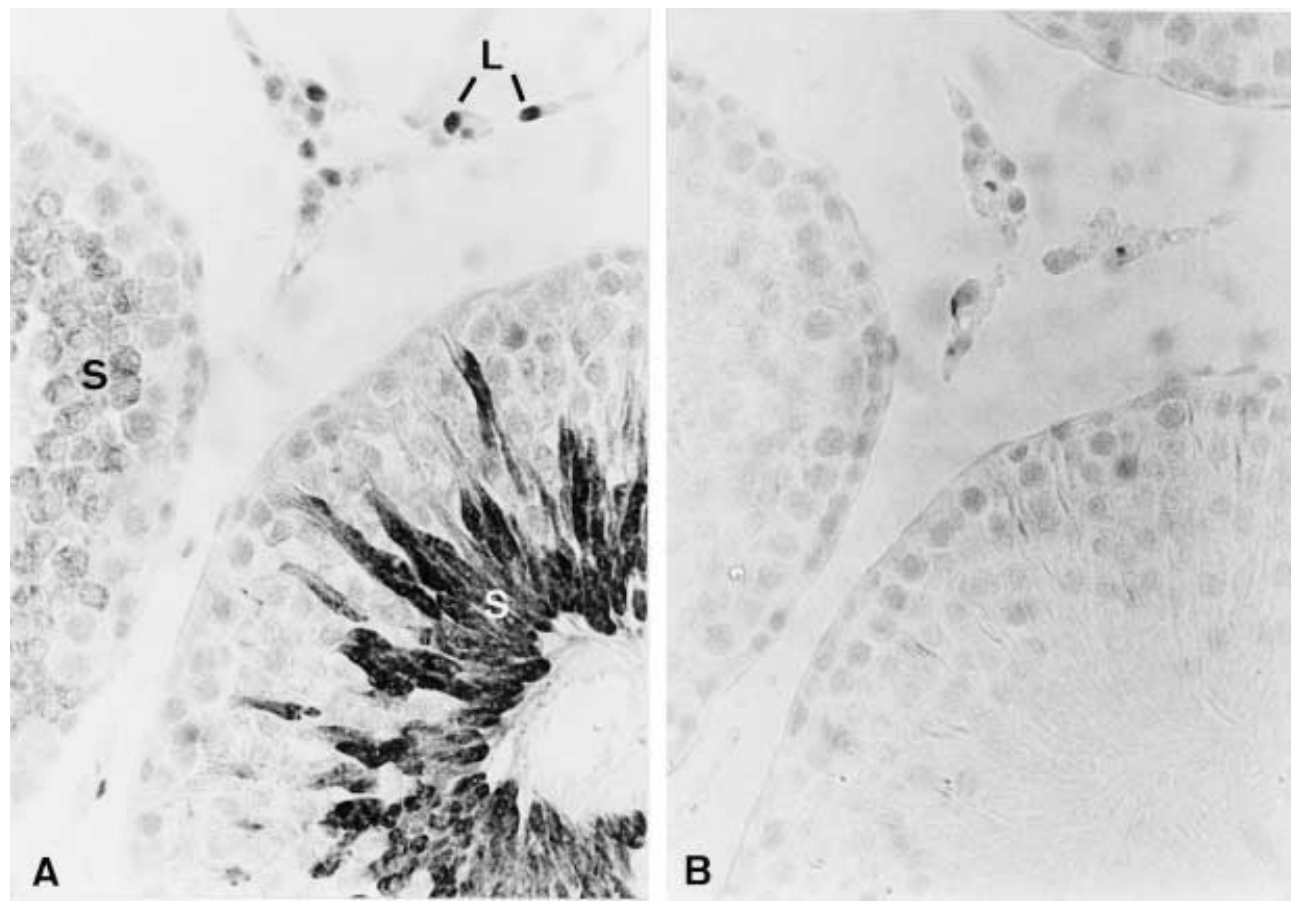

Figure 5 Rat testis. (A) Immunolocalization of ER $\alpha$. In the tubules, diffuse labelling of spermatocytes (S) can be observed while Sertoli cells are unstained. Nuclear staining can also be detected in Leydig cells (L).

(B) Immunoabsorption control. No staining can be detected. $\times 590$. 


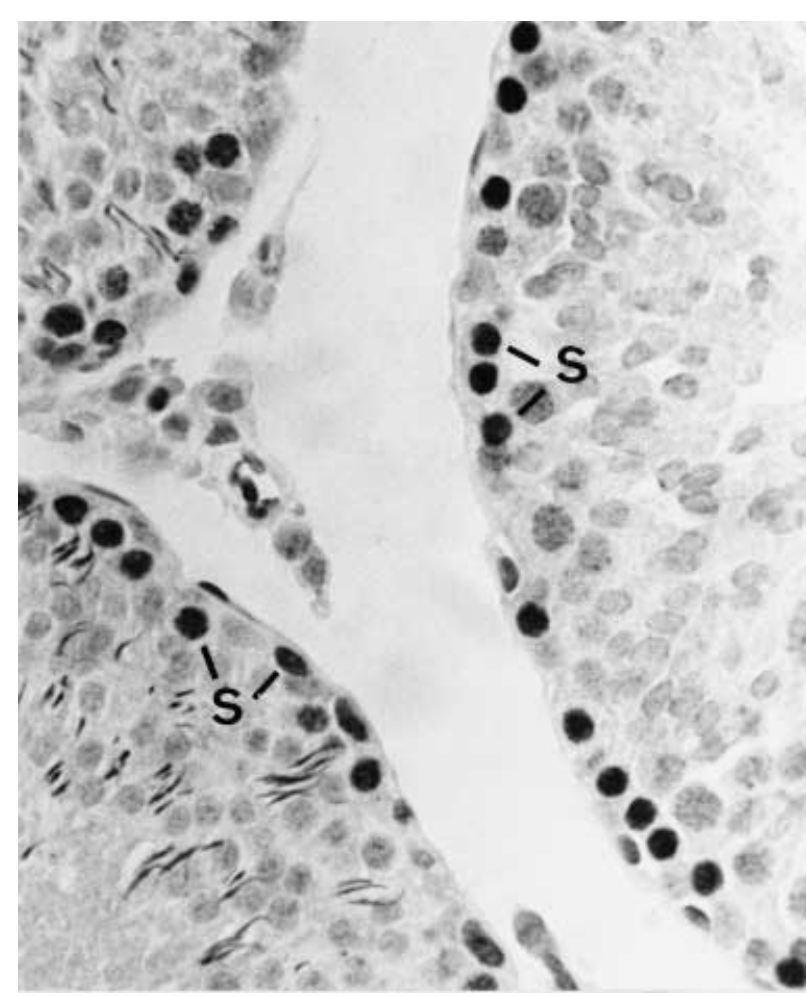

Figure 6 Rat testis. Immunolocalization of ER $\beta$. Nuclear staining is observed in Sertoli cells (S). $\times 590$.

did not exhibit any hybridization signal. The primordial follicles and germinal epithelium also did not appear to express ER $\beta$ mRNA. Immunocytochemical studies generated the same results (not shown). AR immunoreactivity was detected in granulosa cell nuclei in primary, secondary and mature follicles (Fig. 12). The primordial follicles and corpora lutea were unstained, but scattered interstitial cells were immunopositive. No staining could be detected in the germinal epithelium.

In the oviduct, the immunostaining for $\mathrm{ER} \alpha$ produced a nuclear labelling in the vast majority of the epithelial cells. Staining was also observed in nuclei of muscle cells. In the uterus, nuclear staining was found in both glandular and luminal epithelial cells (Fig. 13). A large number of labelled cells was also observed in the stroma in which glands are embedded. Nuclear staining was consistently detected in muscle cells. By in situ hybridization, the same cell types were seen to contain ER $\alpha$ mRNA. No ER $\beta$ expression could be detected by either in situ hybridization or immunostaining. In the oviduct, immunostaining for AR was observed in the nuclei of epithelial, stromal and muscle cells. In the uterus, AR immunoreactivity was detected in nuclei of both epithelial cells lining the glands and those covering the surface (Fig. 14). A large number of stroma cells in the endometrium and muscle cells also exhibited nuclear staining.

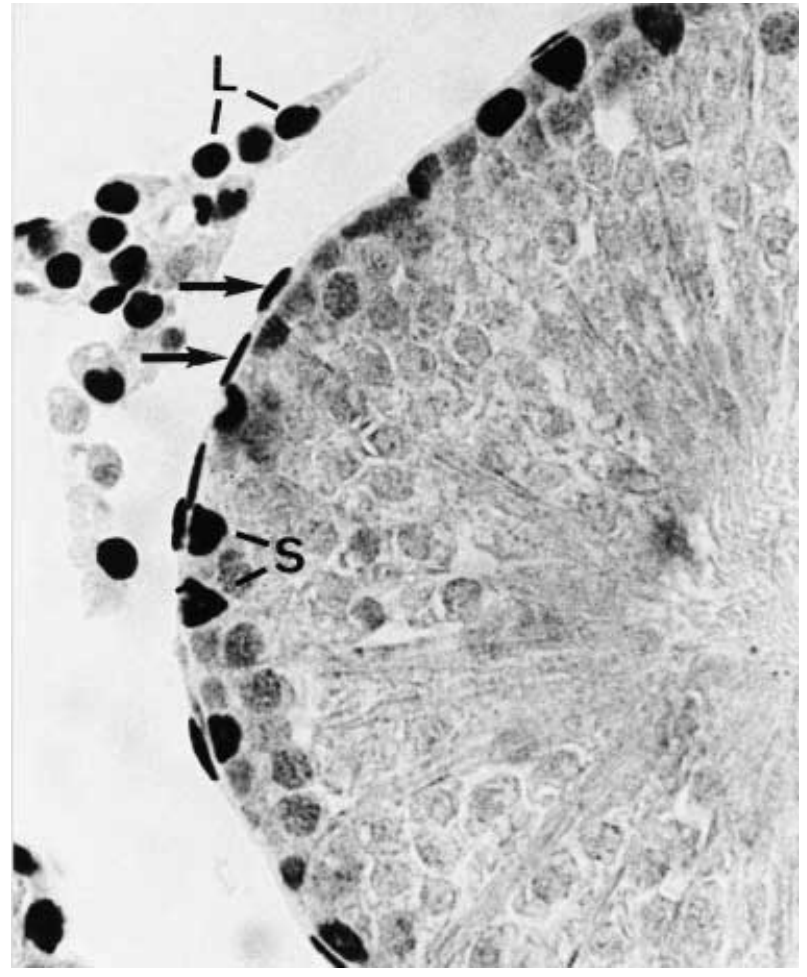

Figure 7 Localization of AR in a section of rat testis. Nuclear staining is present in Sertoli cells (S), peritubular myoid cells (arrows) as well as Leydig cells (L). $\times 590$.

In all the reproductive organs studied, including the pituitary, immunolabelling was completely abolished by immunoabsorption of the antibody with the corresponding antigen (Figs 5B and 12B). Also, in situ hybridization with labelled ER $\alpha$ or ER $\beta$ sense probe produced weak and diffuse labelling, without any localization to specific structures or cells (Fig. 11B).

\section{Discussion}

In the present study, the cellular localization of $E R \alpha, E R \beta$ and $A R$ expression in the reproductive tissues of adult male and female rats have been compared. The specificity of the immunostaining was ascertained by preabsorption of the antiserum with the corresponding antigen, and that of the in situ hybridization by the use of labelled sense probes as negative controls.

\section{Pituitary gland}

In the anterior pituitary gland of rats of both sexes, as evidenced by immunocytochemistry and in situ hybridization, only ER $\alpha$ was found to be expressed. There was no evidence for the presence of ERs in the intermediate and posterior lobes. These results are in agreement with a 

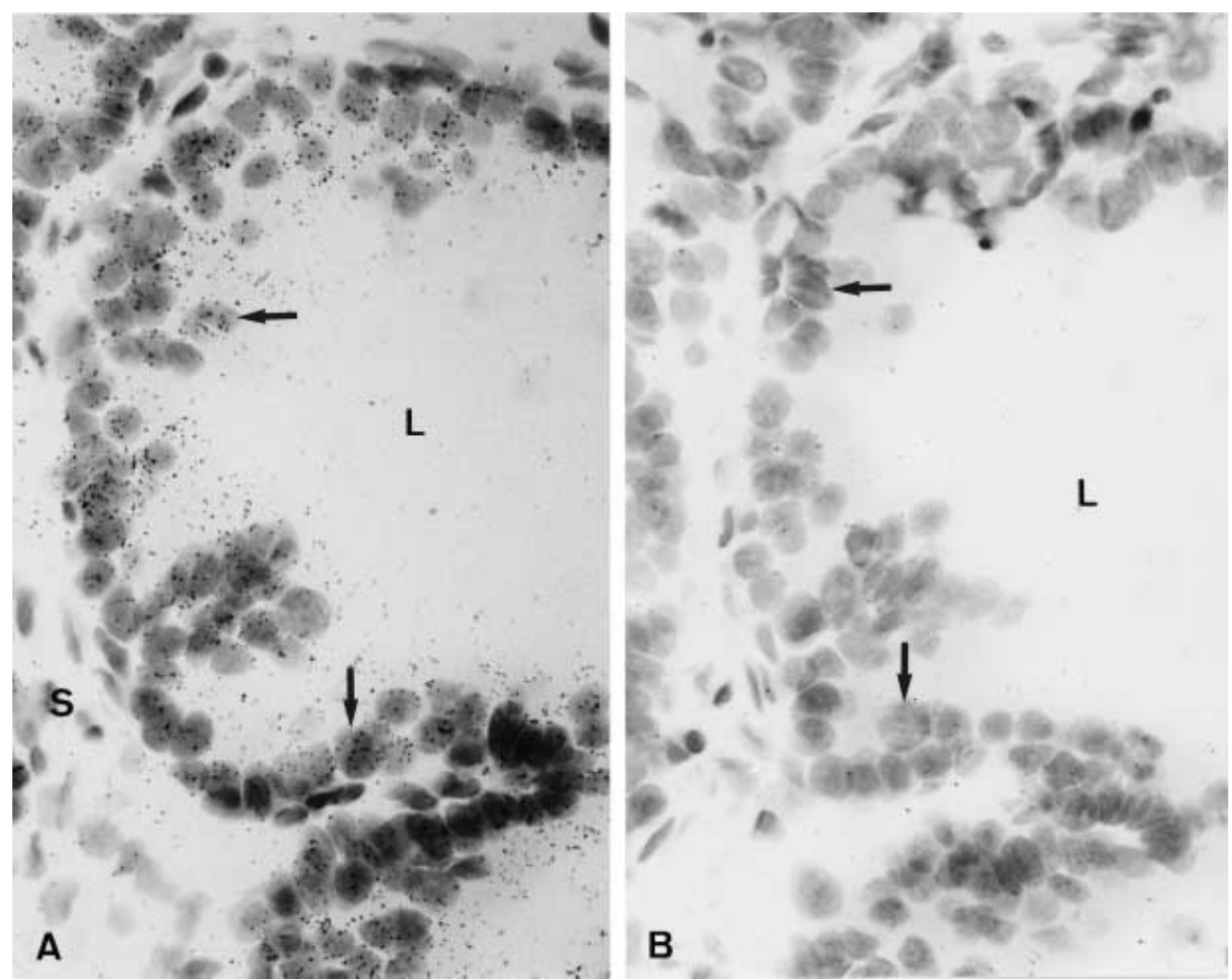

Figure 8 Rat prostate. (A) Localization of ER $\beta$ mRNA by in situ hybridization in rat prostate. Silver grains are overlying the epithelial cells (arrows) of a tubulo-alveolus. The stroma (S) is devoid of reaction. (B) Localization of ER $\alpha$ mRNA. No significant labelling can be detected in secretory epithelial cells or in stroma.

L: lumen. $\times 620$.

previous report indicating that the anterior pituitary expression of $E R \alpha$ is very high while that of $E R \beta$ is very low (Kuiper et al. 1997). In contrast, Mitchner et al. (1998) reported that by combining immunocytochemistry (to localize pituitary hormones and $\operatorname{ER} \alpha$ ) and in situ hybridization (to localize ER mRNAs) ER $\beta$ was present in gonadotrophs, lactotrophs, corticotrophs and folliculosetellate cells at a lower level than ER $\alpha$. Mitchner et al. (1998) also reported that $37 \%$ of the intermediate lobe cells were positive for the ER $\alpha$ protein. The finding that the vast majority of secretory cells $(90 \%)$ in the anterior pituitary contain ERs agrees with previous studies indicating that the secretion of all the pituitary hormones can be directly modulated by oestradiol (Labrie et al. 1983).

The localization of AR in about $50 \%$ of secretory cells in the anterior lobe is in agreement with a report from Kimura et al. (1993) indicating that, in the human pituitary, most of the follicle-stimulating hormone (FSH) and luteinizing hormone cells and some growth hormone cells were immunopositive for AR. In the rat pituitary, AR immunoreactivity was found in nuclei of some secretory cells which were not identified (Sar et al. 1990). These receptors are likely to be involved in the direct action of androgens on gonadotrophin secretion, as observed in cultured anterior pituitary cells (Labrie et al. 1983).

\section{Male reproductive organ}

In the testis, ER $\alpha$ were found to be expressed in Leydig cells and germinal cells, while ER $\beta$ could only be detected in Sertoli cells. These results are in agreement with previous results indicating that the expression of $\operatorname{ER} \alpha$ was predominant in adult rat testis (Kuiper et al. 1997). Paech et al. (1997) showed the absence of ER $\beta$ in the testis of wild-type and ER $\alpha$ knockout (ERKO) male mice. On the other hand, Saunders et al. (1998), using antibodies to a peptide in rat ER $\beta$, found staining in nuclei of Leydig and Sertoli cells and pachytene spermatocytes. The discrepancy between the results from Saunders et al. (1998) and our results might be due to some cross-reactivity of the antibodies used by Saunders et al. (1998) with ER $\alpha$ or other protein(s), although appropriate controls were conducted by this group. Altogether, the results so far obtained on ER localization in testis suggest that oestrogens might play a role in the regulation of Leydig cell 


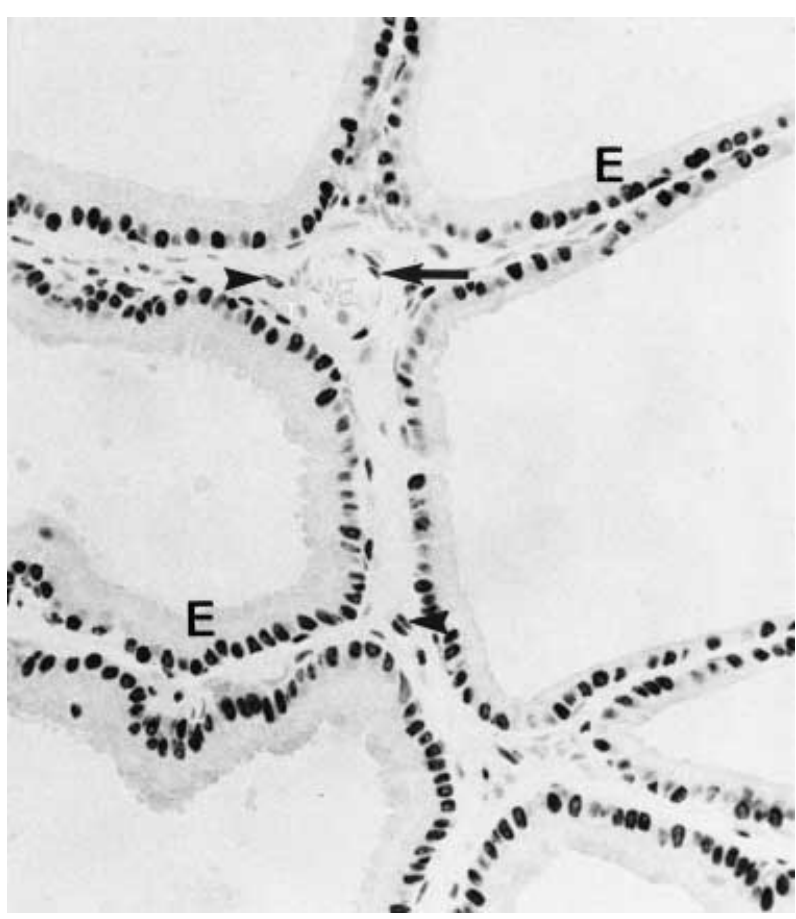

Figure 9 Immunostaining for AR localization in the rat prostate. Nuclear labelling is observed in the majority of epithelial secretory cells (E) of a tubulo-alveolus and in some stromal cells

(arrowheads). Endothelial cells (arrow) of a blood vessel are also immunoreactive. L: lumen. $\times 300$.

secretion and might have a direct influence on germ cell maturation. As previously reported by others (Sar et al. 1990), we have localized AR in nuclei of Sertoli cells. The presence of AR in Sertoli cells can be related to the role of androgens in the regulation of proteins such as androgenbinding protein which are secreted by the Sertoli cells (Wilson \& Griswold 1979). Since Leydig cells, which produce testosterone, also contain ARs, it might be suggested that, in this cell type, androgens exert an intracrine or paracrine activity.

In the prostate, ER $\beta$ was found to be highly expressed in the epithelial secretory cells in tubulo-alveoli, while ER $\alpha$ was not detected either by in situ hybridization or immunocytochemistry. In the human prostate, Enmark et al. (1997) have also detected ER $\beta$ mRNA in epithelial secretory cells, the stroma being totally unlabelled. We have also recently reported that in the monkey ER $\beta$ mRNA is exclusively expressed in epithelial secretory cells (Pelletier et al. 1999). Using RT-PCR, Kuiper et al. (1997) have shown that, in the rat prostate, ER $\beta$ mRNA was highly expressed, while almost no ER $\alpha$ mRNA could be detected. The very low levels of ER $\alpha$ could explain our failure to detect any ER $\alpha$ expression. These previous findings and the present results could indicate that the ER $\beta$ protein is the predominant, if not the only, ER subtype present in the rat prostate. The role of oestrogens

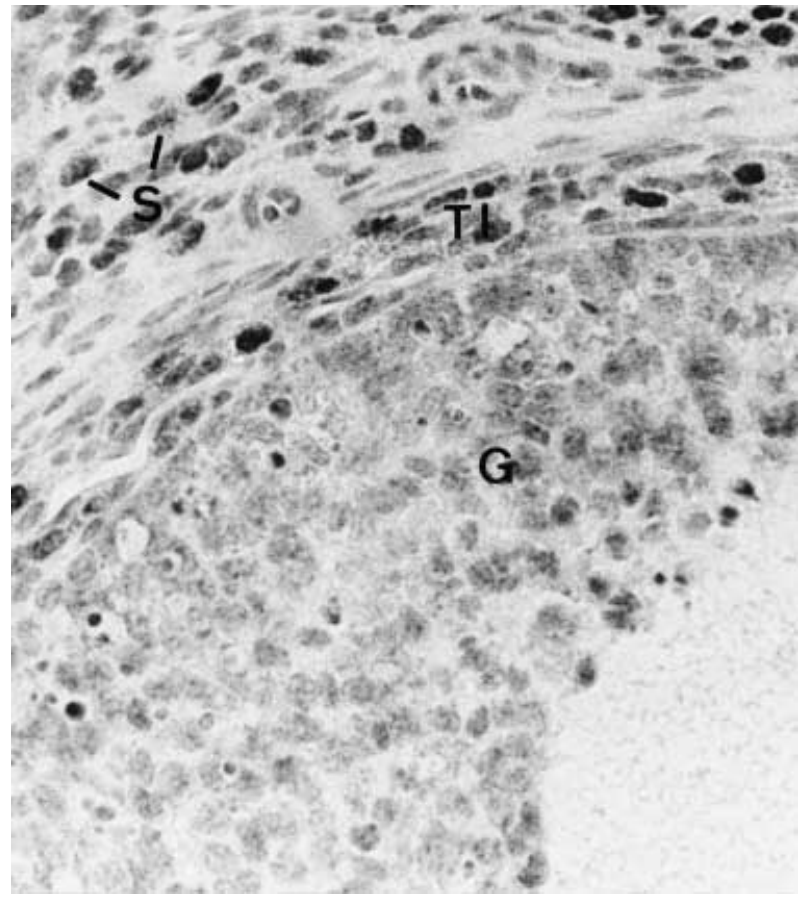

Figure 10 Immunolocalization of $E R \alpha$ in a rat ovary section. Nuclear staining is present in theca interna $(\mathrm{TI})$ and stromal $(\mathrm{S})$ cells. No specific labelling can be observed in the granulosa cells (G) of a growing follicle. $\times 590$.

in prostate development and function is still unclear. Recently Krege et al. (1998) have reported that in 2- to 3-month-old mice lacking ER $\beta$, the histology of the prostate appeared to be normal when compared with age-matched wild-type littermates. The observation that $\mathrm{ER} \alpha$ is highly expressed and $\mathrm{ER} \beta$ poorly expressed in the epididymis is in agreement with a previous report indicating that, in the rat epididymis, ER $\alpha$ mRNA was highly expressed, while the expression of ER $\beta$ mRNA was low (Kuiper et al. 1997).

In the prostate, nuclear staining for AR was found in epithelial cells of the tubulo-alveoli and stromal cells as well as endothelial cells in capillaries and larger blood vessels. Using immunocytochemistry, Sar et al. (1990) could detect AR only in the epithelial cells, the stroma being unstained. Recently, we have reported, in human prostate, the presence of AR in luminal cells of tubuloalveoli and stromal cells as well as endothelial cells (El-Alfy et al. 1999). These results indicate that androgen cannot play a role only in the development and function of the epithelial and stromal cells but may also influence blood vessel development and function. Interestingly, Franck et al. (1998) have shown that, in the rat prostate, testosterone induces a rapid response of the vasculature that largely precedes growth of the glandular epithelium. In the epididymis and seminal vesicles, the localization of $A R$ in 

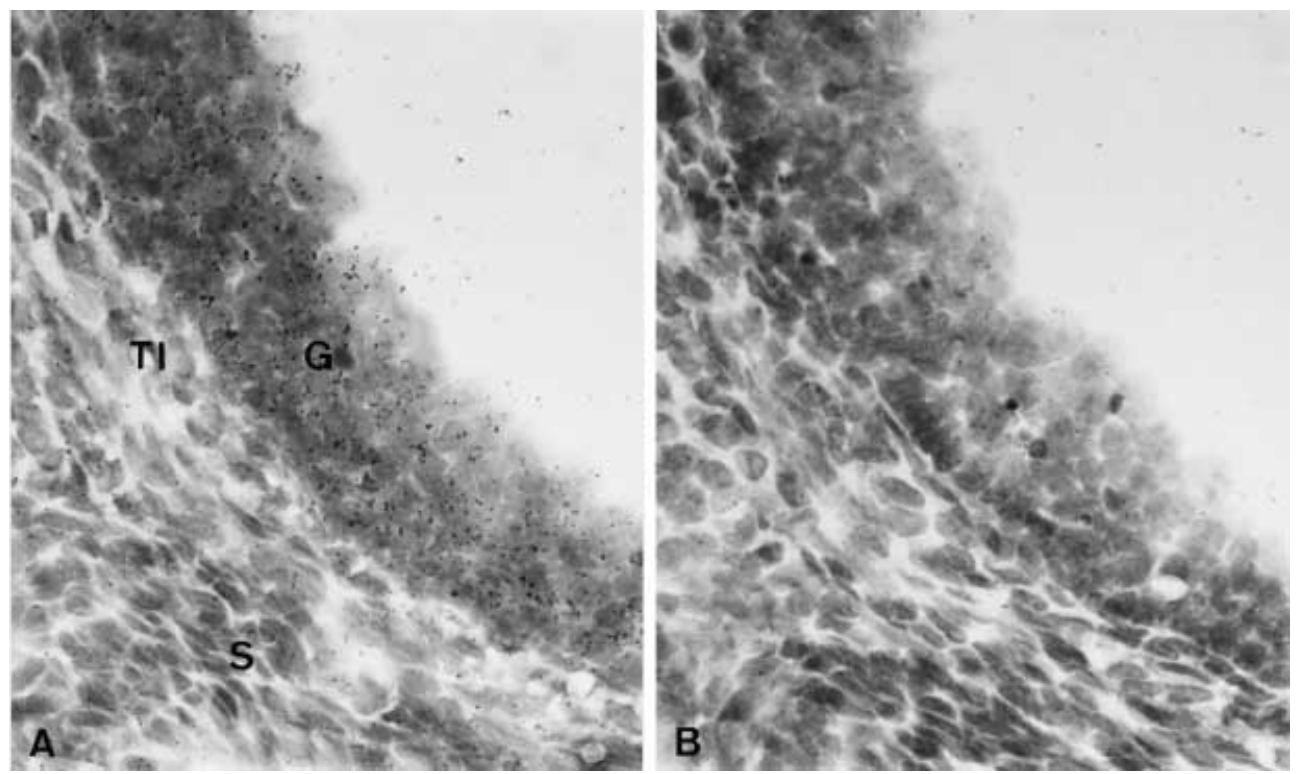

Figure 11 Rat ovary. (A) Hybridization with a labelled ER $\beta$ antisense probe. Granulosa cells (G) of a large follicle exhibit hybridization signal. The theca interna (TI) and stromal (S) cells are unlabelled. (B) Hybridization with a labelled ER $\beta$ sense probe did not generate any labelling. Only a few dispersed grains can be detected. $\times 620$.

nuclei of epithelial and stromal cells is in agreement with a previous report from Sar et al. (1990).

\section{Female reproductive organs}

In the ovary, we observed that ER $\alpha$ was not expressed in the granulosa and corpora lutea cells but was detected in thecal cells, interstitial gland cells and germinal epithelium.
As visualized by in situ hybridization and immunocytochemistry, ER $\beta$ was detected in granulosa cells of growing follicles. These results are similar to those recently reported by Fitzpatrick et al. (1999) and Sar \& Welsch (1999) who used immunocytochemistry to detect the two ER subtypes. The precise role and mechanism of action of oestrogen in the rodent ovary is not well understood. Studies on female mice lacking aromatase, ER $\alpha$ or ER $\beta$
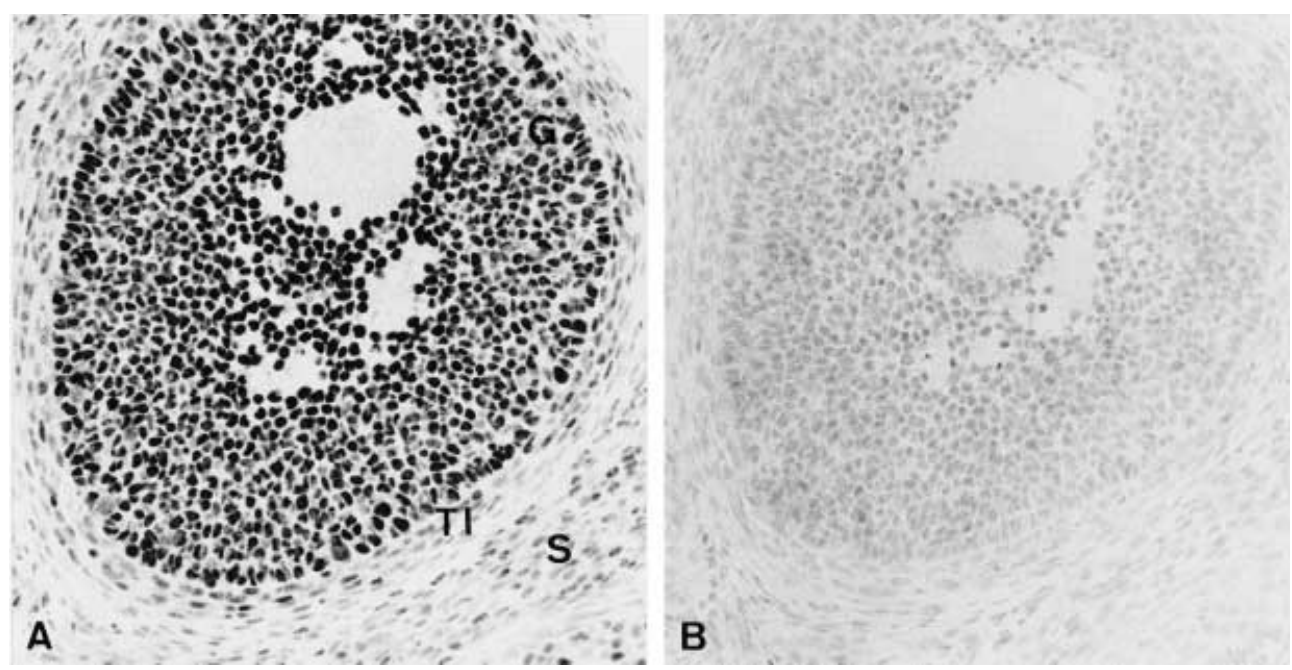

Figure 12 Rat ovary. (A) Immunolocalization of AR. Nuclei of granulosa cells (G) of a growing follicle are strongly stained, while weaker nuclear staining can be observed in theca interna (TI) and stromal cells (S). (B) Control section. Immunoabsorption of the antiserum with the antigen has completely prevented any staining. $\times 300$. 


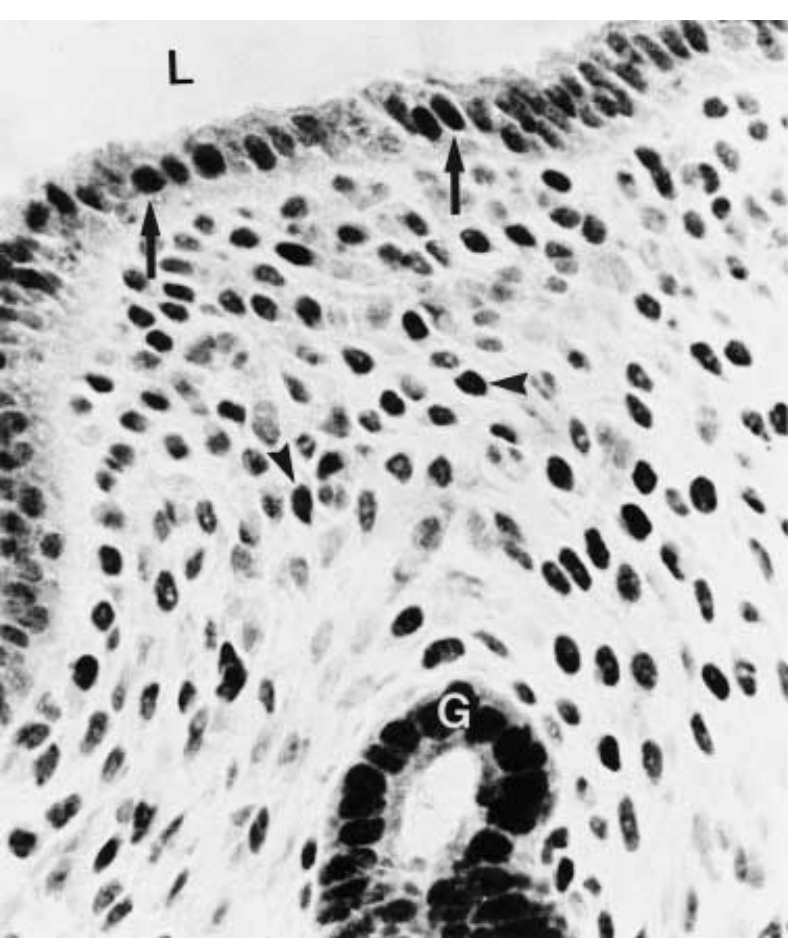

Figure 13 Immunolocalization of ER $\alpha$ in the uterus. Nuclear staining is present in the epithelial cells lining the lumen (arrows) as well as the glandular epithelial cells (G). Stromal cells (arrowheads) also exhibit nuclear staining. L: lumen. $\times 590$.

seem to indicate that, for a normal function, the ovary requires the two known ERs (Lubahn et al. 1993, Fisher et al. 1998, Krege et al. 1998).

The present results indicating the presence of AR immunoreactivity in nuclei of granulosa cell in growing follicles and interstitial gland cells are in complete agreement with a previous report from Tetsuka et al. (1995) indicating that AR and its mRNA are highly expressed in the granulosa cells of rat ovaries. The finding that AR is located in granulosa cells is consistent with the postulate that thecal androgen is a paracrine modulator of granulosa cell function. It has already been shown that testosterone modulates FSH action in developing granulosa cells through the amplification of cyclic-mediated postreceptor signalling initiated by FSH (Hillier \& de Zwart 1982).

In the oviduct and uterus, $\operatorname{ER} \alpha$ but not $\operatorname{ER} \beta$ was found to be expressed in luminal and glandular epithelium as well as in stromal and muscle cells. These findings are very similar to previous findings (Fitzpatrick et al. 1999, Sar \& Welsch 1999) indicating that, by immunocytochemistry, $\operatorname{ER} \alpha$ but not $\operatorname{ER} \beta$ could be detected in the oviduct and uterus. Hiroi et al. (1999) have reported that, in the rat uterus, the nuclei of glandular and luminal epithelial cells were also immunostained with ER $\alpha$ antibodies and that only the nuclei of glandular epithelium cells were stained

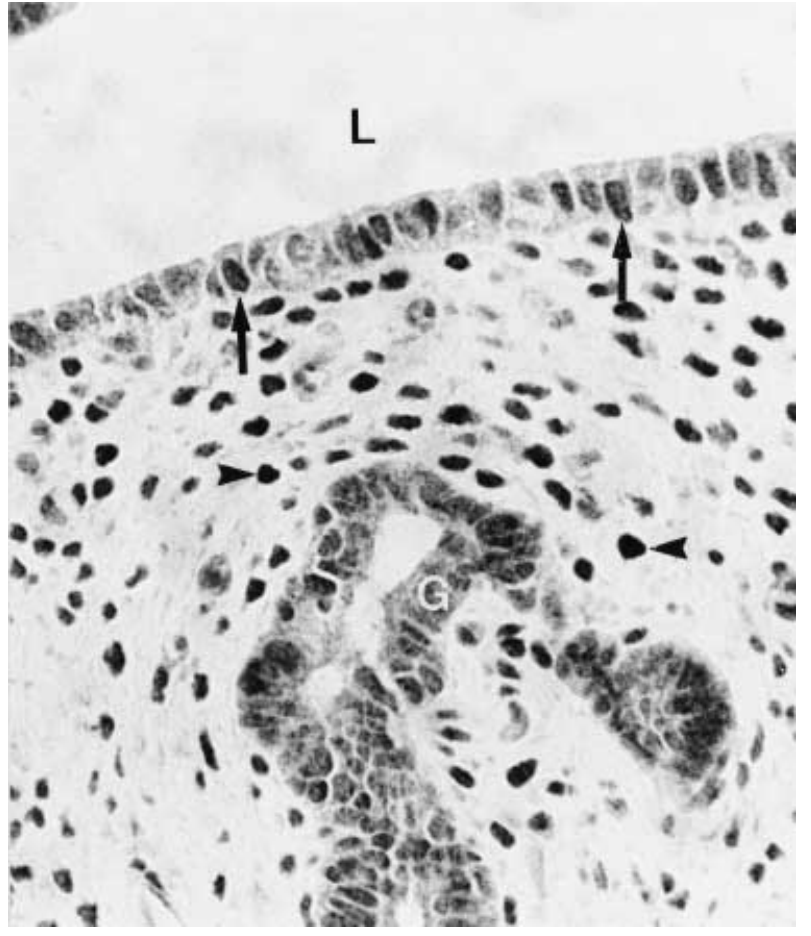

Figure 14 Immunolocalization of $A R$ in the uterus. Nuclear labelling is observed in epithelial cells bordering the lumen (arrows) and glandular epithelial cells (G), Nuclei of stromal cells (arrowheads) are also stained. L: lumen. $\times 590$.

with anti-ER $\beta$. Since RT-PCR analysis has shown low expression of ER $\beta$ mRNA in the rat uterus (Kuiper et al. 1997), it is possible that the approaches used in the present study were not sensitive enough to detect low amounts of $\operatorname{ER} \beta$ at the cellular level. In mice lacking $\operatorname{ER} \beta$, the development of the uterus and oviduct appeared to be normal and these deficient mice, although they had reduced fertility, had normal pregnancy and delivery (Krege et al. 1998). These results then suggest that ER $\beta$ is not essential for the normal functions of the reproductive tract in the female mouse. It is, then, likely that ER $\alpha$ is the ER subtype involved in the mediation of the major effects of oestrogen on the uterus. In fact, in mice deficient in ER $\alpha$ (Lubahn et al. 1993), atrophy of the oviduct and uterus has been observed. Moreover, in these deficient animals, oestradiol administration had no effect on uterine weight while, in wild-type animals, it increased uterine weight and induced hyperhaemia in this organ.

The detection of AR in nuclei of epithelial cells as well as in the stromal and muscle cells in the oviduct and uterus agrees well with previous reports indicating similar localization in the human uterus (Kimura et al. 1993). In the rat, it has been shown, by in situ hybridization, that AR mRNA could be detected in the endometrium and endometrial glands as well as in the myometrium (Hirai et al. 1994). Although androgens have been shown to 
increase uterine weight in the rat (Armstrong \& Papkoff 1976), very little is known about the role of androgens in the uterus. The presence of AR in uterine epithelial, stromal and myometrial cells suggests that androgens may exert a direct influence on the development and function of uterus.

The present findings clearly demonstrate a cell-specific localization of $\mathrm{ER} \alpha, \mathrm{ER} \beta$ and $\mathrm{AR}$ in the reproductive tissues in the rat of both sexes. They contribute to establish the sites of action of androgens and oestrogens, thus leading to a better understanding of the role of these steroids in reproduction in both sexes. In the female, both ER subtypes appear to be involved in ovarian function while, in the uterus, ER $\alpha$ appears to be the predominant subtype. The presence of AR in granulosa and interstitial cells in ovaries and epithelial, stromal and muscle cells in the uterus strongly suggests that androgens can directly modulate the function of these organs. In the male, the differential localization of ER $\alpha$ and ER $\beta$ in the testis and prostate suggests that both ER subtypes are involved in the influence of oestrogens in male reproductive function. The presence of aromatase (Sharpe 1998) in the male genital tract suggests that locally produced oestrogens may play a role more important than that previously thought. In the testis, the localization of AR in the Leydig cells suggests an autocrine or intracrine activity of androgens while the localization of AR in Sertoli cell nuclei can be related to the androgen influence on protein secretion by these cells. The presence of AR in epithelial and stromal cells in the prostate confirms previous findings indicating an androgenic influence on both cellular components.

\section{References}

Armstrong DT \& Papkoff H 1976 Stimulation of aromatization of exogenous and endogenous androgens in ovaries of hypophysectomized rats in vivo by follicle-stimulating hormone. Endocrinology 99 987-991.

Byers M, Juiper GGJM, Gustafsson JA \& Park-Sarge OK 1997 Estrogen receptor-b mRNA expression in rat ovary; downregulation by gonadotropins. Molecular Endocrinology 11 172-182.

Carson-Jurica MA, Schrader WT \& O’Malley BW 1990 Steroid receptor family: structure and functions. Endocrine Reviews $\mathbf{1 1}$ 201-222.

Clark JH, Schrader WT \& O'Malley BW 1992 Mechanisms of action of steroid hormones. In Textbook of Endocrinology, pp 35-90. Ed. J Wilson. Philadelphia: WB Saunders Company.

El-Alfy M, Luu-The V, Huang XF, Berger L, Labrie F \& Pelletier G 1999 Localization of type $517 \beta$-hydroxysteroid dehydrogenase, $3 \beta$-hydroxysteroid dehydrogenase and androgen receptor in the human prostate by in situ hybridization and immunocytochemistry. Endocrinology 140 1481-1491.

Enmark E, Pelto-Huikko M, Grandien K, Lagercrantz S, Lagercrantz J, Fried G, Nordenskjöld M \& Gustafsson JA 1997 Human estrogen receptor b-gene structure, chromosomal localization, and expression pattern. Journal of Clinical Endocrinology and Metabolism 82 4258-4265.

Evans RM 1988 The steroid and thyroid hormone receptor superfamily. Science 240 889-895.
Fisher CR, Graves KH, Parlow AF \& Simpson ER 1998 Characterization of mice deficient in aromatase (ArKO) because of targeted disruption of the cyp19 gene. Proceedings of the National Academy of Sciences of the USA 95 6965-6970.

Fitzpatrick SL, Funkhouser JM, Sindoni DM, Stevis EP, Deecher DC, Bapat AR, Merchenthaler I \& Frail DE 1999 Expression of estrogen receptor- $\beta$ protein in rodent ovary. Endocrinology 140 2581-2591.

Franck J, Lissbrant I, Damber JE \& Berght A 1998 Testosterone stimulates angiogenesis and vascular regrowth in the ventral prostate in castrated adult rats. Endocrinology 139 451-456.

Givalois L, Li S \& Pelletier G 1997 Age-related decrease in the hypothalamic CRH mRNA expression is reduced by dehydroepiandrosterone (DHEA) treatment in male and female rats. Molecular Brain Research 48 107-114.

Hillier SG \& de Zwart FA 1982 Evidence that granulosa cell aromatase induction/activation by FSH is an androgen receptor regulated process in vivo. Endocrinology 109 1303-1305.

Hirai M, Hirata S, Osoda K, Hagibara K \& Kato J 1994 Androgen receptor mRNA in the rat ovary and uterus. Journal of Steroid Biochemistry and Molecular Biology 49 1-7.

Hiroi $\mathrm{H}$, Inoue S, Watanabe T, Goto W, Orimo A, Momoeda M, Tsutsumi O, Taketani Y \& Muramatsu M 1999 Differential immunolocalization of estrogen receptor $\alpha$ and $\beta$ in rat ovary and uterus. Journal of Molecular Endocrinology 22 37-44.

Kimura F, Mizokami A, Oconuma T, Sasano H \& Nagura H 1993 Immunocytochemical localization of androgen receptor with polyclonal antibody in paraffin-embedded human tissues. Journal of Histochemistry and Cytochemistry 4 671-678.

Krege JH, Hodgin JB, Couse JF, Enmark E, Warner M, Mahler JF, Sar M, Korach KS, Gustafsson JA \& Smithies O 1998 Generation and reproductive phenotypes of mice lacking estrogen receptor $\beta$. Proceedings of the National Academy of Sciences of the USA 95 15677-15682.

Kuiper GGJM, Enmark E, Puelto-Huiko M, Nilsson S \& Gustafsson JA 1996 Cloning of a novel estrogen receptor expressed in rat prostate and ovary. Proceedings of the National Academy of Sciences of the USA 93 2925-2930.

Kuiper GJM, Carlsson B, Grandien K, Enmark E, Haggblad J, Nilsson S \& Gustafsson JA 1997 Comparison of the ligand binding specificity and transcript tissue distribution of estrogen receptors $\alpha$ and $\beta$. Endocrinology 138 863-870.

Labrie F, Giguère V, Raymond V, Pelletier G, Veilleux R, Côté J \& Antakly T 1983 Anterior pituitary cells in culture: a precise assay system for hypothalamic and peripheral hormones. In Advances in Cellular Neurobiology, pp 381-406. Eds S Federoff \& L Hertz. New York: Academic Press.

Laflamme N, Nappi RE, Drolet G, Labrie C \& Rivest S 1998 Expression and neuropeptidergic characterization of estrogen receptors $(E R \alpha$ and $E R \beta)$ throughout the rat brain: anatomical evidence of distinct roles of each subtype. Journal of Neurobiology 36 357-378.

Lubahn DB, Moyer JS, Golding TS, Couse JF, Korach KS \& Smithies O 1993 Alteration of reproductive function but not prenatal sexual development after insertional disruption of the mouse estrogen receptor gene. Proceedings of the National Academy of Sciences of the USA 90 11162-11166.

Mangelsdorf DJ, Thummel C, Beato M, Herrlich P, Shulz G, Umesono K, Blumberg B, Kastner P, Manuel M, Chambon P \& Evans RM 1995 The nuclear receptor superfamily: the second decade. Cell 83 835-839.

Mitchner NA, Garlick C \& Ben-Jonathan N 1998 Cellular distribution and gene regulation of estrogen receptors $\alpha$ and $\beta$ in the rat pituitary gland. Endocrinology 139 3976-3983.

Paech K, Webb P, Kuiper GGJM, Wilson S, Gustafsson J-A, Kushner PJ \& Scunlan TS 1997 Differential ligand activation of ER- $\alpha$ and ER- $\beta$ at API sites. Science 277 1508-1510. 
Pelletier G, Dupont E, Simard J, Luu-The V, Bélanger A \& Labrie F 1992 Ontogeny and subcellular localization of $3 \beta$-hydroxysteroid dehydrogenase $(3 \beta-\mathrm{HSD})$ in the human and rat adrenal, ovary and testis. Journal of Steroid Biochemistry and Molecular Biology 43 451-467.

Pelletier G, Luu-The V, Charbonneau A \& Labrie F 1999 Cellular localization of estrogen receptor beta (ER- $\beta$ ) mRNA in cynomolgus monkey reproductive organs. Biology of Reproduction 61 1249-1255.

Ruizeveld de Winter JA, Trapman J, Vermey M, Mulder E, Zegers ND \& Van der Kwast TH 1991 Androgen receptor expression in human tissues: an immunohistochemical study. Journal of Histochemistry and Cytochemistry 39 927-936.

Sar M \& Welsch F 1999 Differential expression of estrogen receptor- $\beta$ and estrogen receptor- $\alpha$ in the rat ovary. Endocrinology 140 963-971.

Sar M, Lubahn DB, French FS \& Wilson EM 1990 Immunohistochemical localization of the androgen receptor in rat and human tissues. Endocrinology 127 3180-3186.
Saunders PTK, Fisher JS, Sharpe RM \& Millar MR 1998 Expression of oestrogen receptor beta $(\mathrm{ER} \beta)$ occurs in multiple cell types, including some germ cells, in the rat testis. Journal of Endocrinology 156 R13-R17.

Sharpe RM 1998 The roles of oestrogen in the male. Trends in Endocrinology and Metabolism 9 371-378.

Tacha DE \& Chen T 1994 Modified antigen retrieval procedure: calibration technique for microwave ovens. Journal of Histotechnology 17 365-366.

Tetsuka M, Whitelaw PF, Bremmer WJ, Millar MR, Smyth CD \& Hillier JG 1995 Developmental regulation of androgen in rat ovary. Journal of Endocrinology 145 535-543.

Wilson RM \& Griswold MD 1979 Secreted proteins from rat Sertoli cells. Experimental Cell Research 123 127-135.

Received 24 September 1999

Accepted 11 January 2000 